\title{
Characteristics of Individual Particles Emitted from an Experimental Burning Chamber with Coal from the Lung Cancer Area of Xuanwei, China
}

\author{
Wenhua Wang ${ }^{1}$, Longyi Shao ${ }^{*}$, Jie Li ${ }^{1}$, Lingli Chang ${ }^{1}$, Daizhou Zhang ${ }^{2}$, Chenchong Zhang ${ }^{3}$, \\ Jingkun Jiang ${ }^{3}$ \\ ${ }^{1}$ State Key Laboratory of Coal Resources and Safe Mining \& College of Geoscience and Surveying Engineering, China \\ University of Mining and Technology (Beijing), Beijing 100083, China \\ ${ }^{2}$ Faculty of Environmental and Symbiotic Sciences, Prefectural University of Kumamoto, Kumamoto 862-8502, Japan \\ ${ }^{3}$ State Key Joint Laboratory of Environmental Simulation and Pollution Control, School of Environment, Tsinghua \\ University, Beijing 100084, China
}

\begin{abstract}
Pollutants emitted from household coal burning in Xuanwei, China, have been recognized as the reason for the high lung cancer mortality and morbidity rates in the area. To examine the characteristics of particles emitted from coal burning, a coal burning-dilution chamber was designed, and the individual particles emitted from the chamber at different burning stages were collected. The morphologies and elemental compositions of the individual particles were analyzed by high resolution transmission electron microscopy. Four types of particles, namely, organic particles, soot particles, S-rich particles, and mineral particles, were identified. The largest percentage of particles by number in the ignition stage, fierceburning stage, and char-burning stage was composed of organic particles (66\%), soot particles (71\%), and mineral particles (73\%), respectively. A distinctive characteristic was the remarkable abundance of $\mathrm{Si}$ - and $\mathrm{Fe}$-rich particles during the char burning stage, compared with emissions from other types of coal. According to the elemental composition, $49 \%$ of the mineral particles were Si-rich, $25 \%$ were $\mathrm{Ca}$-rich, $14 \%$ were $\mathrm{Fe}$-rich, and $7 \%$ were Ti-rich. The Si-rich particles were partly identified as quartz $\left(\mathrm{SiO}_{2}\right)$, the Ca-rich particles were found to be $\mathrm{CaSO}_{4}$ or $\mathrm{CaCO}_{3}$, the Fe-rich particles were primarily $\mathrm{Fe}_{2} \mathrm{O}_{3}$ or $\mathrm{Fe}_{3} \mathrm{O}_{4}$, and the Ti-rich particles were mainly $\mathrm{TiO}_{2}$. Notably, $\mathrm{SiO}_{2}$ is a human carcinogen, and Fe-rich particles possess a high reactive potential with DNA-markers.
\end{abstract}

Keywords: Coal burning; Individual particle analysis; Si-rich particles; Fe-rich particles; Health risk.

\section{INTRODUCTION}

China both produced and consumed a large amount of coal every year. In 2016, about 2.6 billion tons of coal were consumed in China, which accounted for $62.0 \%$ of national primary energy source (National Bureau of Statistics of the People's Republic of China; http://www.stats.gov.cn/tjsj/ndsj/). Emissions from coal burning are important anthropogenic sources of particulate and gaseous pollutants in the atmosphere (Chen et al., 2015; Li et al., 2016a; Cai et al., 2018). Coal contains many potentially harmful substances (Shao et al., 2016; Finkelman and Tian, 2018). During the coal burning process, the harmful substances can be released into the air, causing adverse effect on environment and significantly influence human health (Zhang and Smith, 2007; Pian et al., 2016).

\footnotetext{
* Corresponding author.

E-mail address: ShaoL@cumtb.edu.en
}

Recently, industrial coal combustion shows relative low emission factors of particulate matter (PM) by installing air pollution control devices (Zhou et al., 2016). However, the household coal burning shows distinct high PM emission factors due to the incomplete burning and the absence of dust control devices (Li et al., 2016b). Emission factors of many pollutants from household stoves show two orders of magnitude higher than those from industrial boilers (Zhang et al., 2008). Household coal burning for cooking and heating in Chinese rural areas is popular (Zhu et al., 2012; Zhang et al., 2014; Cai et al., 2018), which causes high indoor PM pollution (Hu et al., 2014), especially in wintertime (Li et al., 2017). As a result, household coal burning can cause human health problems in some rural areas and has attracted attention in recent years (Chen et al., 2015; Tiwari et al., 2015; Li et al., 2017; Lui et al., 2017; Finkelman and Tian, 2018).

Xuanwei City, located in Yunnan Province, southwestern China, is rich in coal, iron, copper and other mines (Xiao et al., 2012). Xuanwei has the highest lung cancer morbidity and mortality rates in China, especially in rural areas (He 
et al., 1991; Xiao et al., 2012; Kim et al., 2014). Most of the important findings have suggested that the high lung cancer rates in Xuanwei are attributed to indoor smoky coal burning (Lan et al., 2008; Barone-Adesi et al., 2012; Hosgood et al., 2013; Lui et al., 2017). For example, according to a recent population-based case-control study, the lung cancer risk was significantly associated with the smoky coal use while the lung cancer association with cigarette was null in hazardous coal users (Kim et al., 2014).

Knowledge of detailed physical and chemical characteristics of coal burning-derived fine particles has important significance in the field of explaining the mechanism of high lung cancer incidence in Xuanwei ( $\mathrm{Lu}$ et al., 2017). To our knowledge, there is few information available for revealing the evolution of individual fine particles throughout the different burning stages in Xuanwei. In this study, a set of chamber dilution measurement system was set up and the individual fine particles in different burning stages of Xuanwei coal were collected; characteristics of individual particles were analyzed by using transmission electron microscopy (TEM) with energy dispersive X-ray spectroscopy (EDX).

\section{MATERIALS AND METHODS}

\section{Coal Burning-Dilution Chamber}

Fig. 1 shows the coal burning-dilution chamber measurement system used for generating coal-burning particles. The whole sealed room was $\sim 10 \mathrm{~m}^{3}$ and at the center of the room installed a household stove sized $460 \times$ $410 \times 985 \mathrm{~mm}(\mathrm{NS} 18-17,18 \mathrm{~kW}$; Laowan Company; Beijing, China). The stove has a thermal efficiency of more than $70 \%$. The air was filtered and then pumped into the sealed room. The filtered PM mass concentration was less than $1 \mu \mathrm{g} \mathrm{m}^{-3}$, which was negligible compared with the high PM levels during coal burning. Emissions from the stove are diluted with the filtered air in the sealed room and drawn into a circular pipe. The cold water entered the stove wall and then hot water flowed out to simulate a water heating process.

Raw coal samples used in this experiment were from Yantang coal mine in Xuanwei City $\left(26.23055^{\circ} \mathrm{N}\right.$, $\left.104.09751^{\circ} \mathrm{E}\right)$. Details of the coal information can be found in previous studies (Hao et al., 2013; Shao et al., 2015). The coal samples ( $\sim 10 \mathrm{~kg}$ ) were ignited by propane gas with a flow rate of $3 \mathrm{~L} \mathrm{~min}^{-1}$ and the ignition time was $\sim 10 \mathrm{~min}$. Details of the burning-dilution system has been previously described (Li et al., 2016b, c; Zhou et al., 2016).

\section{Sample Collection}

A DKL-2 single-stage cascade impactor was used to collect particles on carbon coated Cooper $(\mathrm{Cu})$ grids (300-mesh; Tianld Co.; Beijing, China). The sampler has a $0.5-\mathrm{mm}$ (diameter) jet nozzle. The flow rate was $1 \mathrm{~L} \mathrm{~min}^{-1}$. The collection efficiency of this sampler is $\sim 100 \%$ at $0.5 \mu \mathrm{m}$ if the particle density is $2 \mathrm{~g} \mathrm{~cm}^{-3}$ (Li et al., 2016d). The collected samples were sealed and placed in an air dryer before analysis (Wang et al., 2017).

To better characterize the individual fine particles throughout the burning process, we collected particles in different burning stages, including ignition stage, fierce burning stage and char burning stage. The ignition stage was characterized by low burning temperature and high PM concentration. We collected the samples at $\sim 15$ minutes after the propane ignition started and the sampling duration for one sample was $\sim 10 \mathrm{~s}$. In fierce burning stages, the burning temperature was high and rapidly increased to its peak of more than $1000^{\circ} \mathrm{C}$. We collected the samples after the peak temperature occurred at $\sim 1$ hour and the sampling duration for one sample was $\sim 25 \mathrm{~s}$. In char burning stages, the burning temperature gradually decreased to $\sim 600^{\circ} \mathrm{C}$ from its peak. The PM loading was low and the char burning

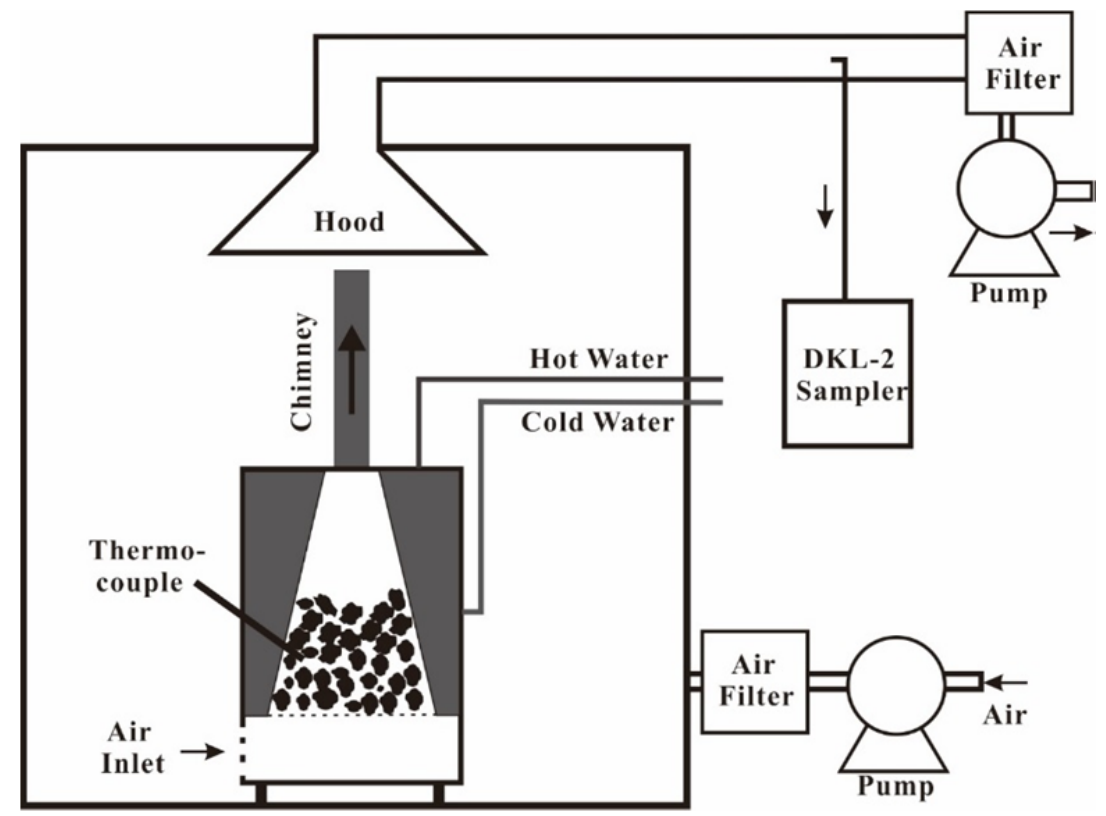

Fig. 1. Coal burning-dilution chamber measurement system used for generating coal-burning particles. 
was dominant. We collected the samples at $\sim 2.3$ hours and the sampling duration for one sample was $\sim 60 \mathrm{~s}$. When the above sampling process was completed, we repeated the above sampling process with another $10 \mathrm{~kg}$ of coal samples. Therefore, two set of individual particle samples were collected.

\section{TEM Analysis}

Hitachi H-8100 TEM (Hitachi, Ltd; Tokyo, Japan) was used to analyze the individual fine particles and the accelerate voltage was $200 \mathrm{kV}$. EDX was used to semi-quantitatively acquire the elemental composition with an acquisition time $\sim 30 \mathrm{~s}$ and the elements with atomic number higher than 6 can be detected. Copper was not included in our analysis because the TEM grids were made of $\mathrm{Cu}$ (Wang et al., 2018).

\section{RESULTS}

\section{Particle Types}

TEM-EDX can be adequately applied to identify individual fine particles. Based on the morphology and elemental composition, individual fine particles were classified into two groups: carbonaceous and noncarbonaceous particles. Carbonaceous particles included soot particles and organic particles; non-carbonaceous particles included S-rich particles and mineral particles. Detailed characteristics of individual particles were shown in Table 1.

Soot particles were mainly composed of $\mathrm{C}$ and $\mathrm{O}$. They showed distinct chain-like (Fig. 2(a)) or aggregate morphologies (Fig. 2(b)) with hundreds of C-rich spheres, which displayed an onion-like structure with disordered graphic layers under high resolution TEM images (Fig. 2(c)).

Organic particles also mainly consisted of $\mathrm{C}$ and $\mathrm{O}$. Some of the organic particles showed inhomogeneous structure with darker and lighter areas under TEM images (Figs. 2(d) and 2(e)); these types of organic particles were near-spherical. The other organic particles showed homogeneous structure and they were spherical or irregularshaped without any holes (Fig. 2(f)). The organic particles did

Table 1. Types and characteristices of individual particles emitted from the burning of Xuanwei coal.

\begin{tabular}{|c|c|c|c|}
\hline Particle groups & Particle types & Major elements & Morphologies \\
\hline \multirow[t]{2}{*}{$\begin{array}{l}\text { Carbonaceous } \\
\text { particles }\end{array}$} & Soot & $\mathrm{C}$ and $\mathrm{O}$ & $\begin{array}{l}\text { Chain-like or aggregate morphologies with hundreds of } \\
\text { C-rich spheres }\end{array}$ \\
\hline & Organic & $\mathrm{C}$ and $\mathrm{O}$ & $\begin{array}{l}\text { Partly showed inhomogeneous structure with darker and } \\
\text { lighter areas; partly showed homogeneous structure with } \\
\text { spherical or irregular shapes }\end{array}$ \\
\hline \multirow{2}{*}{$\begin{array}{l}\text { Non- } \\
\text { carbonaceous } \\
\text { particles }\end{array}$} & Mineral & $\begin{array}{l}\mathrm{Si}, \mathrm{Fe}, \mathrm{Mg}, \mathrm{Al}, \mathrm{Ca} \\
\mathrm{Ti}, \mathrm{K} \text {, and } \mathrm{P}\end{array}$ & $\begin{array}{l}\text { Irregular shaped and tended to have a larger diameter } \\
\text { compared with other types of particles }\end{array}$ \\
\hline & S-rich & $\mathrm{S}, \mathrm{O}, \mathrm{N}$, and $\mathrm{K}$ & $\begin{array}{l}\text { Foam-like; beam sensitive and easily decomposed with } \\
\text { high energy electron beam irradiation }\end{array}$ \\
\hline
\end{tabular}

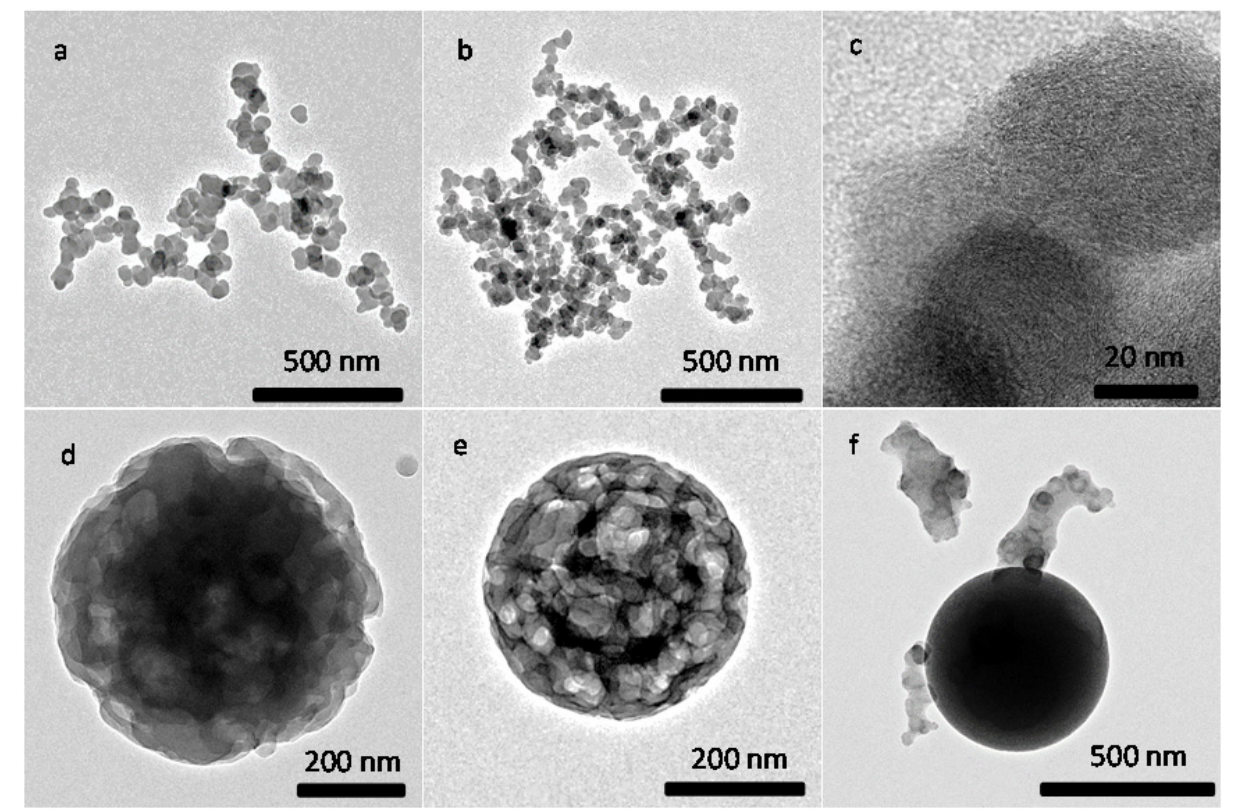

Fig. 2. TEM images of carbonaceous particles. (a) chain-like soot, (b) aggregated soot, (c) onion-like structured high magnification soot, (d-e) inhomogeneous near-spherical organic particles, and (f) homogeneous irregular-shaped or spherical organic particles. 
not show the graphic layers as seen in soot particles under high resolution TEM images.

S-rich particles were foam-like; they were beam-sensitive and easily decomposed with high energy electron beam irradiation (Figs. 3(a) and 3(b)). Some of S-rich particles were mainly composed of $\mathrm{S}$ and $\mathrm{O}$ (Fig. 3(e)); they were believed to be ammonium sulphates (Fu et al., 2012). The other S-rich particles were mainly composed of S, O and $\mathrm{K}$ (Fig. 3(f)), which were believed to be $\mathrm{K}_{2} \mathrm{SO}_{4}$ (Li et al., 2010).

Mineral particles were irregular-shaped and tended to have a larger diameter compared with other types of particles. They were mainly composed of crustal mineral elements (e.g., Si, Ca, Al, Fe, Na, K, Mg, P). According to their highest elemental composition (Okada et al., 2005), the mineral particles were subdivided into Si-rich (Figs. 3(c) and 3(d)), Ca-rich (Figs. 3(i) and 3(j)), Fe-rich (Fig. 3(k)), Ti-rich (Fig. 3(1)) and other types. Some Si-rich particles only contained $\mathrm{Si}$ and $\mathrm{O}$ (Figs. 3(c) and 3(g)), and they were identified as $\mathrm{SiO}_{2}$; the other $\mathrm{Si}$-rich particles were mainly composed of $\mathrm{Si}, \mathrm{Al}$ and $\mathrm{O}$, and/or with minor $\mathrm{Ca}$, $\mathrm{Mg}, \mathrm{Fe}, \mathrm{Na}$, and K (Figs. 3(d) and 3(h)), and were identified as aluminum silicate. Ca-rich particles mainly consisted of $\mathrm{Ca}, \mathrm{O}, \mathrm{C}$, and S, (Figs. 3(m) and 3(n)) and were identified as $\mathrm{CaCO}_{3}$ or $\mathrm{CaSO}_{4}$. Fe-rich particles mainly consisted of $\mathrm{Fe}$ and $\mathrm{O}$, and they were mainly $\mathrm{Fe}_{2} \mathrm{O}_{3}$ or $\mathrm{Fe}_{3} \mathrm{O}_{4}$ (Figs. 3(k) and 3(o)). Ti-rich particles mainly consisted of $\mathrm{Ti}$ and $\mathrm{O}$, and were identified as $\mathrm{TiO}_{2}$ (Figs. 3(l) and 3(p)).

\section{Number Fractions in Different Burning Stages}

Fig. 4 showed the low magnification TEM images of individual fine particles in different burning stages. Distinct characteristics of fine particles in different burning stages can be seen. The relative number percentage of different types of individual particle in different burning stages was calculated as shown in Fig. 5. We analyzed 873 individual particles in total among 6 TEM samples. In the ignition stage, carbonaceous particles were predominant, with organic particles $66 \%$ and soot particles $31 \%$ in number, respectively. In the fierce burning stage, carbonaceous particles were also predominant, but the soot particles $(71 \%)$ were the highest among all analyzed particles, followed by organic particles $(28 \%)$. In char burning stage, mineral particles were the highest in relative number percentage of all analyzed individual particles, at $73 \%$, followed by organic particles (12\%), soot particles (8\%) and S-rich particles (7\%). Among all analyzed mineral particles, Si-rich particles were predominant, at $49 \%$, followed by Ca-rich (25\%), Ferich $(14 \%)$, Ti-rich $(7 \%)$ and other types (Fig. 6). S-rich particles accounted for a small percentage throughout the whole burning process in this experiment.
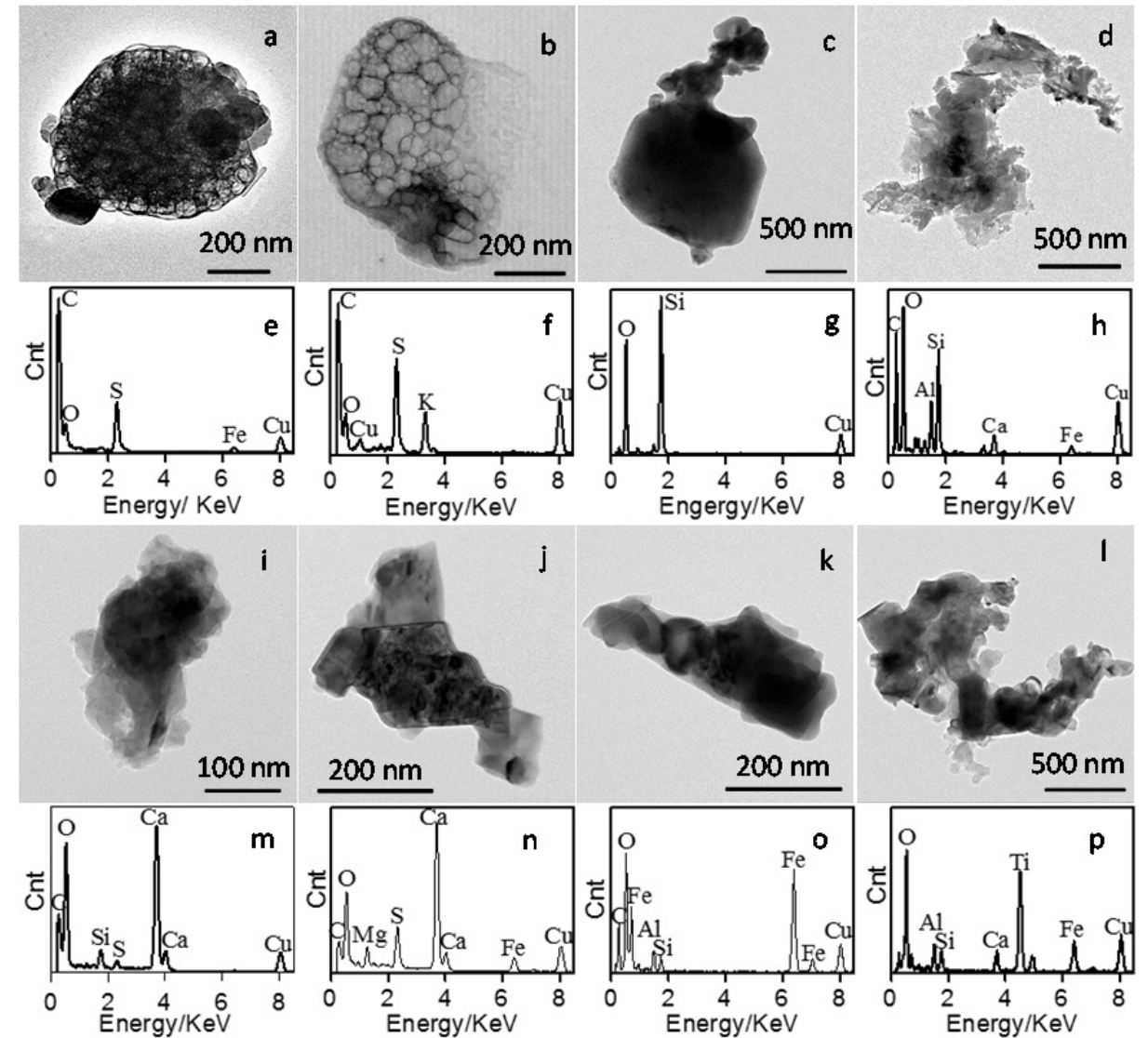

Fig. 3. TEM images and elemental compositions of non-carbonaceous particles. (a-b) S-rich particles and (e-f) their elemental compositions, (c) quartz $\left(\mathrm{SiO}_{2}\right)$ and $(\mathrm{g})$ its elemental composition, (d) aluminum silicate and $(\mathrm{h})$ its elemental composition, (i) $\mathrm{CaCO}_{3}$ and (m) its elemental composition, (j) $\mathrm{CaSO}_{4}$ and (n) its elemental composition, (k) Fe-rich particles and (o) its elemental composition, (l) $\mathrm{TiO}_{2}$ particles and (p) its elemental composition. 


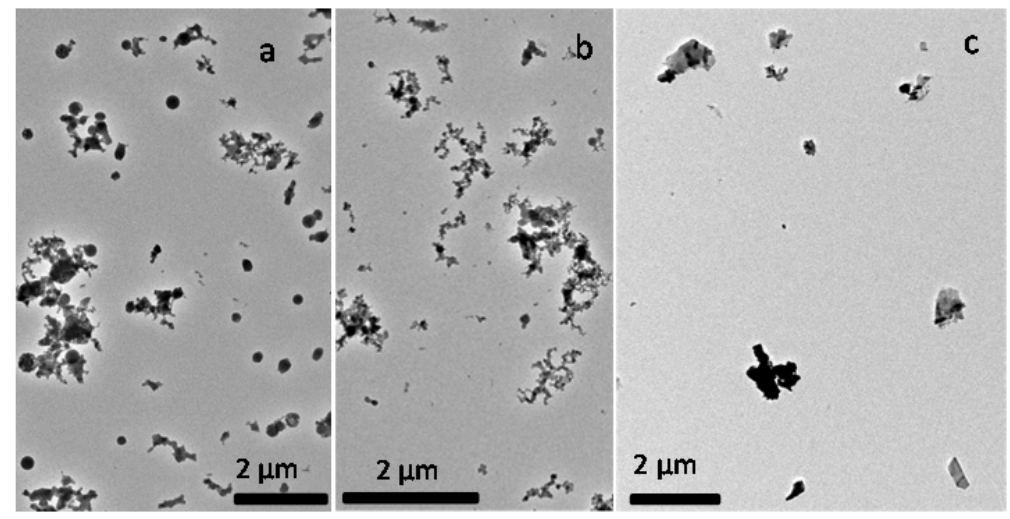

Fig. 4. Low magnification TEM images of individual particles in different burning stages. (a) organic particles dominated in ignition stage, (b) soot particles dominated in fierce burning stage, and (c) mineral particles dominated in char burning stage.

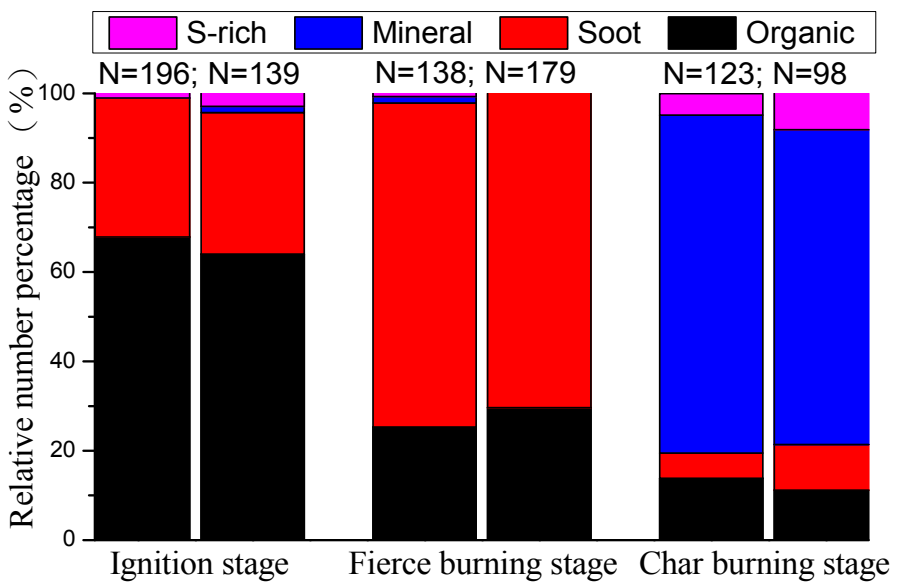

Fig. 5. Relative number percentage of individual particles in different burning stages. $\mathrm{N}$ represents the particle number analyzed.

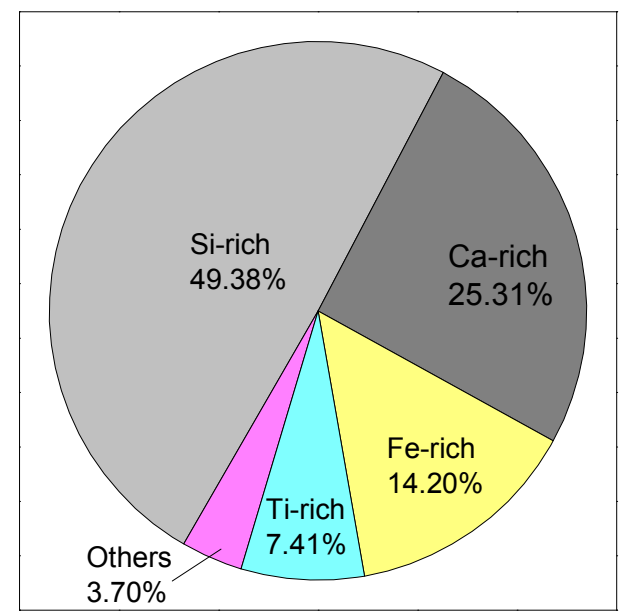

Fig. 6. Relative number percentage of mineral particles in the char burning stage.

\section{DISCUSSIONS}

Xuanwei City has the highest lung cancer morbidity and mortality rates in China, which are attributed to local household coal burning (Lan et al., 2008; Barone-Adesi et al., 2012; Hosgood et al., 2013; Lui et al., 2017). Detailed knowledge of physical and chemical characteristics of burning-derived individual particles might help to explain the toxicological effects. Considering that the PM emissions in different burning stages show different characteristics (Fig. 5), we hence discuss the PM emission characteristics in different burning stages.

\section{Formation of Carbonaceous Particles in Ignition and Fierce Burning Stages}

Household coal burning in China has attracted much attention in recent years because it can emit various kinds of important pollutants (Chen et al., 2015). Household coal burning has low burning efficiency because of the low burning temperature, as a result, household coal burning can often emit a large fraction of carbonaceous particles (Li et al., 2016b).

In the ignition and fierce burning stages, coal chunks undergo pyrolysis and generate a high number of organic volatiles and most of them are burned completely, forming $\mathrm{H}_{2} \mathrm{O}$ and $\mathrm{CO}_{2}$ (Zhou et al., 2016; Li et al., 2017). However, a small number of the volatile matters are not oxidized or 
partially oxidized, forming organic aerosols (Wang et al., 2015). Some of the gas phase high-molecular-weight hydrocarbons, such as PAHs can undergo nucleation, condensation or polymerization reactions in very short time periods of $\sim 5 \mathrm{~ms}$ to compete with oxidation in the absence of oxygen, forming soot particles (Ma et al., 1996; Fletcher et al., 1997; Richter and Howard, 2000; Mansurov, 2005; Apicella et al., 2017; Xiao et al., 2017). Therefore, the coal pyrolysis product escaped from the burning region and formed either organic or soot particles in the exhaust.

Both the ignition and fierce burning stages were dominated by carbonaceous particles. However, the organic particles were predominant in relative number percentage in the ignition stage while the soot particles were predominant in the fierce burning stage. It should be mentioned that PM emissions from the ignition stage were much higher than in the fierce burning stage and the absolute value of soot particles was much higher in the ignition stage than the fierce burning stage. The higher relative number percentage of soot particles in the fierce burning stage might be related to the burning temperature, concentration of oxygen and the variation of pyrolysis product (Ma et al., 1996; Fletcher et al., 1997; Richter and Howard, 2000; Mansurov, 2005; Apicella et al., 2017; Xiao et al., 2017), and further research is needed in the future.

Only a few of mineral particles were found in the first two burning stages. They may come from the soil dust coated on the surface of the coal when stored and transported or emit from the inner coal chunks along with the emission of pyrolysis product.

\section{Non-Carbonaceous Particles Influenced by the \\ Composition of Coal}

The volatile materials of coal have been mostly consumed in the first two burning stages, and the char burning became dominant in the following stage (Zhou et al., 2016).
During the coal burning process, the minerals in coal were partially deposited as bottom ash and partially emitted into atmosphere (Lu et al., 2016). With the decreasing of volatile content, mineral particles were dominant in the char burning stage and the type of mineral particles were related with the mineral composition of coal chunks.

The elemental composition of individual particles emitted in char burning stage was complicated. Result from the EDX showed that over 17 elements have been detected in individual non-carbonaceous particles, including $\mathrm{O}, \mathrm{Si}, \mathrm{Fe}, \mathrm{Mg}, \mathrm{Al}, \mathrm{Ca}, \mathrm{Ti}, \mathrm{S}, \mathrm{K}, \mathrm{P}, \mathrm{Na}, \mathrm{Cl}, \mathrm{Sr}, \mathrm{Ni}, \mathrm{V}, \mathrm{Mn}$ and $\mathrm{Zn}$, as shown in Fig. 7. O occurred on all analyzed particles. $\mathrm{Si}, \mathrm{Fe}, \mathrm{Mg}, \mathrm{Al}, \mathrm{Ca}$, Ti occurred in more than half of all analyzed particles. The result was consistent with the content of major elements in coals from Xuanwei City (Hao et al., 2013; Shao et al., 2015).

Minerals such as quartz $\left(\mathrm{SiO}_{2}\right)$, chamosite $\left(\left[\mathrm{Fe}^{2+}, \mathrm{Mg}\right]_{5} \mathrm{Al}\left[\mathrm{AlSi}_{3} \mathrm{O}_{10}\right]\right)$, calcite $\left(\mathrm{CaCO}_{3}\right), \quad$ kaolinite $\left(\mathrm{Al}_{2} \mathrm{SiO}_{5}\left([\mathrm{OH}]_{4}\right)\right.$, and anatase $\left(\mathrm{TiO}_{2}\right)$ in Xuanwei coal have been found by Shao et al. (2015). Because of the relative low burning temperature, most of the mineral particles were emitted at its original elemental compositions. For example, some quartz $\left(\mathrm{SiO}_{2}\right)$, aluminates, calcite $\left(\mathrm{CaCO}_{3}\right)$ and anatase $\left(\mathrm{TiO}_{2}\right)$ (Figs. 3(c), 3(d), 3(i), and 3(l) from Xuanwei coal can be identified in burning-derived individual particles in this study. However, there were also some new particle formation through chemical reactions. For example, some Fe-rich particles partially resulted from the oxidized product of chamosite or pyrite $\left(4 \mathrm{FeS}_{2}+11 \mathrm{O}_{2}\right.$ $\left.=2 \mathrm{Fe}_{2} \mathrm{O}_{3}+8 \mathrm{SO}_{2}\right)(\mathrm{Lu}$ et al., 2016). As shown in Fig. 6 , the individual mineral particles were predominant in Si-rich (49\%), followed by Ca-rich (25\%), Fe-rich (14\%), Ti-rich (7\%) and other types (4\%), which is consistent with the main mineral content of Xuanwei coal.

S-rich particles accounted for a small percentage throughout the whole burning process in this experiment.

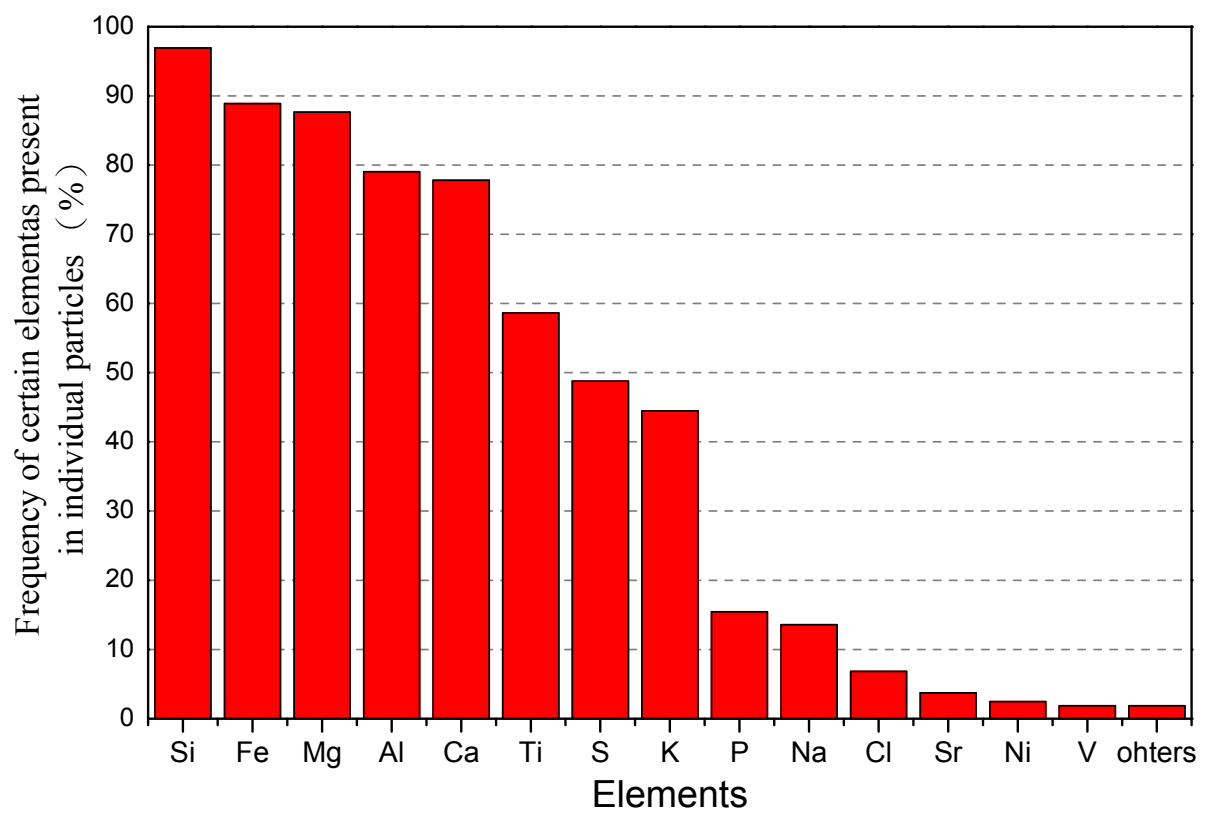

Fig. 7. Frequency of certain elements present in individual non-carbonaceous particles in char burning stage. 
Previous study showed that the emission of S-rich particles were related with the sulfur content of raw coals and the burning of high sulfur content coal can emitted more S-rich particles (Hou et al., 2018). The total sulfur content of Xuanwei coal is extraordinary low, ranging from 0.06 to $0.64 \%$ (Shao et al., 2015), resulting in the lower number percentage of S-rich particles.

\section{Implications for Health Risk}

Coal combustions can emit large amounts of polycyclic aromatic hydrocarbons (PAHs) which is harmful to human health (Downward et al., 2014). Previous studies have shown that the epidemic diseases might be related to indoor PAHs released from the coal burning in Xuanwei (Mumford et al., 1995; Liu et al., 2017). However, Tian (2005) found there was no obvious relationship between PAHs and lung cancer in a geographical correlation study in Xuanwei. We find a large number of organic particles in the ignition and fierce burning stages in this experiments. Since part of the organic particles belongs to PAHs, further research regarding PAHs is needed in the future.

Mineral particles have been recognized as respiratory hazards (Donaldson and Borm, 2006). The crystalline fine mineral particles were more hazardous when compared with the amorphous mineral ones (Murphy et al., 1998). Most of the mineral particles in household coal burning showed the crystalline structures due to the low burning temperature (Lu et al., 2016).

The content of quartz in Xuanwei coal was almost ten times that found in the other coals (Large et al., 2009). Tian (2005) and Tian et al. (2008) have found that most of the burning-derived Si-rich particles were quartz. Si-rich particles accounted for a large number percentage of all analyzed mineral particles, at $49 \%$, much higher than the average (28\%) of burning-derived particles from the coals of Zhijin, Datong, Dongsheng, Yinchuan and Jingxi (Hou et al., 2018). In 1996, IARC have classified quartz as a Group 1 substance-carcinogen for humans (International Agency for Research on Cancer; http://monographs.iarc.fr/ ENG/Classification/index.php). It should be mentioned that higher number percentage of Si-rich particles were also observed by Lu et al. (2016, 2017); but the Si-rich particles were not found by using TEM at Fuyuan County, the neighboring area of Xuanwei (Lu et al., 2017).

Fe-rich particles accounted for $14.2 \%$, which was nearly two times of the average ( $8 \%$ ) coal burning-derived particles from the coals of Zhijin, Datong, Dongsheng, Yinchuan and Jingxi (Hou et al., 2018). Also, 78\% of analyzed mineral particles contained Fe. The reactive oxygen species (ROS) can be formed through chemical reactions: $\left(\mathrm{Fe}^{2+}+\mathrm{H}_{2} \mathrm{O}_{2} \rightarrow\right.$ $\mathrm{Fe}^{3+}+\mathrm{OH}+\mathrm{OH}^{-}$) (Valavanidis et al., 2000; Ambroz et al., 2001; Kim et al., 2001; Breheny, 2014). Once these Fecontaining individual particles were inhaled into the lung, they may do harm to the lung tissues.

\section{CONCLUSIONS}

The detailed characteristics of individual particles emitted during the different stages of burning Xuanwei coal were identified in this study. Four types of individual particles were classified, viz., organic particles, soot particles, S-rich particles, and mineral particles. Number-wise, our results showed that organic particles $(66 \%)$, soot particles $(71 \%)$, and mineral particles $(73 \%)$ were predominant in the ignition stage, fierce burning stage, and char burning stage, respectively, while S-rich particles accounted only for a small percentage.

According to the elemental composition, the mineral portion comprised Si-rich, Ca-rich, Ti-rich, Fe-rich, and other types of particles. In the char burning stage, the particles that were rich in $\mathrm{Si}$, partially identified as quartz or aluminum silicate, were dominant $(49 \%)$; followed by ones that were Ca-rich $(25 \%)$, which were identified as $\mathrm{CaCO}_{3}$ or $\mathrm{CaSO}_{4} ; \mathrm{Fe}$-rich (14\%), which mainly consisted of $\mathrm{Fe}$ and $\mathrm{O}$ and were recognized as $\mathrm{Fe}_{3} \mathrm{O}_{4}$ or $\mathrm{Fe}_{2} \mathrm{O}_{3}$; Ti-rich (7\%), which were dominated by $\mathrm{Ti}$ and $\mathrm{O}$ and recognized as $\mathrm{TiO}_{2}$; and other types (4\%).

\section{ACKNOWLEDGEMENTS}

This work was supported by the Projects of International Cooperation and Exchanges NSFC (Grant No. 41571130031) and National Natural Science Foundation of China (Grant No. 41572090 and No. 41807305).

\section{REFERENCE}

Ambroz, H.B., Bradshaw, T.K., Kemp, T.J., Kornacka, E.M. and Przybytniak, G.K. (2001). Role of iron ions in damage to DNA: Influence of ionising radiation, UV light and $\mathrm{H}_{2} \mathrm{O}_{2}$. J. Photochem. Photobiol. A 142: 9-18.

Apicella, B., Senneca, O., Russo, C., Heuer, S., Cortese, L., Cerciello, F., Scherer, V., Schiemann, M. and Ciajolo, A. (2017). Separation and characterization of carbonaceous particulate (soot and char) produced from fast pyrolysis of coal in inert and $\mathrm{CO}_{2}$ atmospheres. Fuel 201: 118123.

Barone-Adesi, F., Chapman, R.S., Silverman, D.T., He, X.Z., Hu, W., Vermeulen, R., Ning, B.F., Fraumeni, J.F., Rothman, N. and Lan, Q. (2012). Risk of lung cancer associated with domestic use of coal in Xuanwei, China: retrospective cohort study. Br. Med. J. 345: e5414.

Breheny, D. (2014). Environmental reactive oxygen species (ROS) and cancer, In Systems biology of free radicals and antioxidants, Laher, I. (Ed.), Springer Berlin Heidelberg, Heidelberg, Berlin, Germany, pp. 2853-2872.

Cai, S., Li, Q., Wang, S., Chen, J., Ding, D., Zhao, B., Yang, D. and Hao, J. (2018). Pollutant emissions from residential combustion and reduction strategies estimated via a village-based emission inventory in Beijing. Environ. Pollut. 238: 230-237.

Chen, Y.J., Tian, C.G., Feng, Y.L., Zhi, G.R., Li, J. and Zhang, G. (2015). Measurements of emission factors of $\mathrm{PM}_{2.5}, \mathrm{OC}, \mathrm{EC}$, and $\mathrm{BC}$ for household stoves of coal combustion in China. Atmos. Environ. 109: 190-196.

Donaldson, K. and Borm, P. (2006). Particle toxicology. CRC Press, Taylor \& Francis Group, Boca Raton, FL, 
USA.

Downward, G.S., Hu, W., Large, D., Veld, H., Xu, J., Reiss, B., Wu, G., Wei, F.,Chapman, R.S. and Rothman, N. (2014). Heterogeneity in coal composition and implications for lung cancer risk in Xuanwei and Fuyuan counties, China. Environ. Int. 68: 94-104.

Finkelman, R.B. and Tian, L.W. (2018). The health impacts of coal use in China. Int. Geol. Rev. 60: 579-589.

Fletcher, T.H., Ma, J., Rigby, J.R., Brown, A.L. and Webb, B.W. (1997). Soot in coal combustion systems. Prog. Energy Combust. Sci. 23: 283-301.

Fu, H., Zhang, M., Li, W., Chen, J., Wang, L., Quan, X. and Wang, W. (2012). Morphology, composition and mixing state of individual carbonaceous aerosol in urban Shanghai. Atmos.Chem. Phys. 12: 693-707.

Hao, X., Yi, F., Ren, J., Zhang, R., Liu, D. and Lv, S. (2013). Characteristics of the fine quartz particles from the local coal combustion in Xuanwei, Yunnan Province. Res. Environ. Sci. 26: 1043-1049. (in Chinese with English Abstract)

He, X.Z., Chen, W., Liu, Z.Y. and Chapman, R.S. (1991). An epidemiological study of lung cancer in Xuan Wei County, China: Current progress. Case-control study on lung cancer and cooking fuel. Environ. Health Perspect. 94: 9-13.

Hosgood, H.D., Chapman, R.S., He, X.Z., Hu, W., Tian, L.W., Liu, L.Z., Lai, H., Chen, W., Rothman, N. and Lan, Q. (2013). History of lung disease and risk of lung cancer in a population with high household fuel combustion exposures in rural China. Lung Cancer 81: 343-346.

Hou, C., Shao, L.Y., Zhao, C.M., Wang, J., Liu, J.X.,Geng, C.M. (2018). Characterization of coal burning-derived individual particles emitted from an experimental domestic stove. J. Environ. Sci. 71: 45-55.

Hu, W., Downward, G.S., Reiss, B., Xu, J., Bassig, B.A., Hosgood, H.D., Zhang, L.L., Seow, W.J., Wu, G.P., Chapman, R.S., Tian, L.W., Wei, F.S., Vermeulen, R. and Lan, Q. (2014). Personal and indoor $\mathrm{PM}_{2.5}$ exposure from burning solid fuels in vented and unvented stoves in a rural region of China with a high incidence of lung cancer. Environ. Sci. Technol.48: 8456-8464.

Kim, B.Y., Han, M.J. and Chung, A.S. (2001). Effects of reactive oxygen species on proliferation of chinese hamster lung fibroblast (V79) cells. Free Radical Biol. Med. 30: 686-698.

Kim, C., Chapman, R.S., Hu, W., He, X.Z., Hosgood, H.D., Liu, L.Z., Lai, H., Chen, W., Silverman, D.T., Vermeulen, R., Tian, L.W., Bassig, B., Shen, M., Zhang, Y.W., Ma, S.G., Rothman, N. and Lan, Q. (2014). Smoky coal, tobacco smoking, and lung cancer risk in Xuanwei, China. Lung Cancer 84: 31-35.

Lan, Q., He, X.Z., Shen, M., Tian, L.W., Liu, L.Z., Lai, H., Chen, W., Berndt, S.I., Hosgood, H.D., Lee, K.M., Zheng, T.Z., Blair, A. and Chapman, R.S. (2008). Variation in lung cancer risk by smoky coal subtype in Xuanwei, China. Int. J. Cancer 123: 2164-2169.

Large, D.J., Kelly, S., Spiro, B., Tian, L.W., Shao, L.Y., Finkelman, R., Zhang, M., Somerfield, C., Plint, S., Ali,
Y. and Zhou, Y.P. (2009). Silica-volatile interaction and the geological cause of the Xuan Wei Lung cancer epidemic. Environ. Sci. Technol. 43: 9016-9021.

Li, Q., Jiang, J.K., Cai, S.Y., Zhou, W., Wang, S.X., Duan, L. and Hao, J.M. (2016a). Gaseous ammonia emissions from coal and biomass combustion in household stoves with different combustion efficiencies. Environ. Sci. Technol. Lett. 3: 98-103.

Li, Q., Jiang, J.K., Zhang, Q., Zhou, W., Cai, S.Y., Duan, L., Ge, S. and Hao, J.M. (2016b). Influences of coal size, volatile matter content, and additive on primary particulate matter emissions from household stove combustion. Fuel 182: 780-787.

Li, Q., Li, X.H., Jiang, J.K., Duan, L., Ge, S., Zhang, Q., Deng, J.G., Wang, S.X. and Hao, J.M. (2016c). Semicoke briquettes: Towards reducing emissions of primary $\mathrm{PM}_{2.5}$, particulate carbon, and carbon monoxide from household coal combustion in China. Sci. Rep. 6: 10.

Li, Q., Jiang, J.K., Wang, S.X., Rumchev, K., MeadHunter, R., Morawska, L. and Hao, J.M. (2017). Impacts of household coal and biomass combustion on indoor and ambient air quality in China: Current status and implication. Sci. Total Environ 576: 347-361.

Li, W.J., Shao, L.Y., and Buseck, P.R. (2010). Haze types in beijing and the influence of agricultural biomass burning. Atmos. Chem. Phys. 10: 8119-8130.

Li, W.J., Sun, J.X., Xu, L., Shi, Z.B., Riemer, N., Sun, Y.L., Fu, P.Q., Zhang, J.C., Lin, Y.T., Wang, X.F., Shao, L.Y., Chen, J.M., Zhang, X.Y., Wang, Z.F. and Wang, W.X. (2016d). A conceptual framework for mixing structures in individual aerosol particles. J. Geophys. Res. 121: 13784-13798.

Lu, S.L., Hao, X.J., Liu, D.Y., Wang, Q.X., Zhang, W.C., Liu, P.W., Zhang, R.C., Yu, S., Pan, R.Q., Wu, M.H., Yonemochi, S. and Wang, Q.Y. (2016). Mineralogical characterization of ambient fine/ultrafine particles emitted from xuanwei c1 coal combustion. Atmos. Res. 169: 1723.

Lu, S.L., Tan, Z.Y., Liu, P.W., Zhao, H., Liu, D.Y., Yu, S., Cheng, P., Win, M.S., Hu, J.W., Tian, L.W., Wu, M.H., Yonemochi, S. and Wang, Q.Y. (2017). Single particle aerosol mass spectrometry of coal combustion particles associated with high lung cancer rates in Xuanwei and Fuyuan, China. Chemosphere 186: 278-286.

Lui, K.H., Bandowe, B.A.M., Tian, L.W., Chan, C.S., Cao, J.J., Ning, Z., Lee, S.C. and Ho, K.F. (2017). Cancer risk from polycyclic aromatic compounds in fine particulate matter generated from household coal combustion in Xuanwei, China. Chemosphere 169: 660-668.

Ma, J., Fletcher, T.H. and Webb, B.W. (1996). Conversion of coal tar to soot during coal pyrolysis in a post-flame environment. Symp. (Int.) Combust. 26: 3161-3167.

Mansurov, Z.A. (2005). Soot formation in combustion processes (review). Combust. Explos. Shock Waves 41: 727-744.

Mumford, J.L., Li, X., Hu, F., Lu, X.B. and Chuang, J.C. (1995). Human exposure and dosimetry of polycyclic aromatic hydrocarbons in urine from Xuan Wei, China with high lung cancer mortality, associated with exposure 
to unvented coal smoke. Carcinogenesis 16: 3031.

Murphy, S.A., BeruBe, K.A., Pooley, F.D. and Richards, R.J. (1998). The response of lung epithelium to well characterised fine particles. Life Sci. 62: 1789-1799.

Okada, K., Qin, Y. and Kai, K. (2005). Elemental composition and mixing properties of atmospheric mineral particles collected in Hohhot, China. Atmos. Res. 73: 45-67.

Pian, W., Cheng, W., Niu, H. and Fan, J. (2016). TEM study of fine particles from coal-fired power plant ambient air. World J. Eng. 14: 311-316.

Richter, H. and Howard, J.B. (2000). Formation of polycyclic aromatic hydrocarbons and their growth to soot - A review of chemical reaction pathways. Prog. Energy Combust. Sci. 26: 565-608.

Shao, L.Y., Wang, J., Hou, H.H., Zhang, M.Q., Wang, H., Spiro, B., Large, D. and Zhou, Y.P. (2015). Geochemistry of the $\mathrm{C} 1$ coal of latest Permian during mass extinction in Xuanwei, Yunnan. Acta Geol. Sin. 89: 7. (in Chinese with English Abstract)

Shao, L.Y., Hou, C., Geng, C.M., Liu, J.X., Hu, Y., Wang, J., Jones, T., Zhao, C.M. and BeruBe, K. (2016). The oxidative potential of $\mathrm{PM}_{10}$ from coal, briquettes and wood charcoal burnt in an experimental domestic stove. Atmos. Environ. 127: 372-381.

Tian, L. (2005). Coal combustion emissions and lung cancer in Xuanwei, China. Ph.D. Thesis. University of California, Berkeley, USA.

Tian, L.W., Dai, S.F., Wang, J.F., Huang, Y.C., Ho, S.C., Zhou, Y., Lucas, D. and Koshland, C.P. (2008). Nanoquartz in Late Permian $\mathrm{C} 1$ coal and the high incidence of female lung cancer in the Pearl River Origin Area: A retrospective cohort study. BMC Public Health 8: 12.

Tiwari, M., Sahu, S.K. and Pandit, G.G. (2015). Inhalation risk assessment of PAH exposure due to combustion aerosols generated from household fuels. Aerosol Air Qual. Res. 15: 582-590.

Valavanidis, A., Salika, A. and Theodoropoulou, A. (2000). Generation of hydroxyl radicals by urban suspended particulate air matter. the role of iron ions. Atmos. Environ. 34: 2379-2386.

Wang, W.H., Shao, L.Y., Guo, M.L., Hou, C., Xing, J.P. and Wu, F. (2017). Physicochemical properties of individual airborne particles in Beijing during pollution periods. Aerosol Air Qual. Res. 17: 3209-3219.
Wang, W.H., Shao, L.Y., Xing, J.P., Li, J., Chang, L.L. and Li, W.J. (2018). Physicochemical characteristics of individual aerosol particles during the 2015 China victory day parade in Beijing. Atmosphere 9: 40.

Wang, X.F., Cotter, E., Iyer, K.N., Fang, J.X., Williams, B.J. and Biswas, P. (2015). Relationship between pyrolysis products and organic aerosols formed during coal combustion. Proc. Combust. Inst. 35: 2347-2354.

Xiao, Y., Shao, Y., Yu, X. and Zhou, G. (2012). The epidemic status and risk factors of lung cancer in Xuanwei City, Yunnan Province, China. Front. Med. 6: 388-394.

Xiao, Z.K., Tang, Y., Zhuo, J.K. and Yao, Q. (2017). Effect of the interaction between sodium and soot on fine particle formation in the early stage of coal combustion. Fuel 206: 546-554.

Zhang, H.F., Zhu, T., Wang, S.X., Hao, J.M., Mestl, H.E.S., Alnes, L.W.H., Aunan, K., Dong, Z.Q., Ma, L.Y., Hu, Y., Zhang, M., Mellouki, A.W., Chai, F. and Wang, S.L. (2014). Indoor emissions of carbonaceous aerosol and other air pollutants from household fuel burning in Southwest China. Aerosol Air Qual. Res. 14: 1779-1288.

Zhang, J.J. and Smith, K.R. (2007). Household air pollution from coal and biomass fuels in China: Measurements, health impacts, and interventions. Environ. Health Perspect. 115: 848-855.

Zhang, Y.X., Schauer, J.J., Zhang, Y.H., Zeng, L.M., Wei, Y.J., Liu, Y. and Shao, M. (2008). Characteristics of particulate carbon emissions from real-world Chinese coal combustion. Environ. Sci. Technol. 42: 5068-5073.

Zhou, W., Jiang, J.K., Duan, L. and Hao, J.M. (2016). Evolution of submicrometer organic aerosols during a complete residential coal combustion process. Environ. Sci. Technol. 50: 7861-7869.

Zhu, C.S., Cao, J.J., Shen, Z.X., Liu, S.X., Zhang, T., Zhao, Z.Z., Xu, H.M. and Zhang, E.K. (2012). Indoor and outdoor chemical components of $\mathrm{PM}_{2.5}$ in the rural areas of northwestern China. Aerosol Air Qual. Res. 12: 1157-116. 